\title{
ポリブチレンテレフタレート/ポリビスフェノール $\mathrm{A}$ カーボネートブレンド物のモルフォロジー*
}

\author{
信州大学 裁維学部 大越 豊・近田 淳雄 -三枝 伸司・青木 茂人・ \\ 井出 俊彦・鳥海浩一郎
}

\section{MORPHOLOGY OF POLY(BUTYLENE TEREPHTHALATE)/ POLY(BISPHENOL A CARBONATE) MELT BLENDS}

\author{
By Yutaka Ohkoshi, Atsuo Konda, Shinji Mieda, Shigeto Aoki, \\ Toshihiko Ide, and Koichiro Toriumi
}

Faculty of Textile Science and Technology 3-15-1 Tokida, Ueda, Nagano Pref., 386 Japan

\begin{abstract}
Morphology and mechanical properties of poly(butylene terephthalate) (PBT)/ poly(bisphenol A carbonate) (PC) and PBT/PC/di-n-octadecyl phosphate (DNOP) melt blends have been examined as a function of PC fraction with DSC, X-ray diffraction, FT-IR and SEM. Mechanical properties and dynamic viscoelastic properties of the blend filaments were also studied. The cross section of $90 / 10 / 0.5$ blend etched by 4 vol\% $\mathrm{CH}_{2} \mathrm{Cl}_{2} / \mathrm{CCl}_{4}$ mixture shows one phase structure, while network structure of PBT rich phase is observed for $70 / 30 / 0.5$ blends, further the $10 / 90 / 0.5$ blend is dissolved by the mixture. Two glass transitions are observed in DSC curves for $70 / 30 / 0.5$ to $30 / 70 / 0.5$ blends. The lower glass transi. tion occurs at about the constant temperature, while the temperature of higher glass transition increases with the PC fraction. It is considered that the above two transitions are ascribed to PBT rich and PC rich phase, respectively. For $100 / 0$ to $50 / 50$ blends, dynamic storage modulus drops drastically at the glass transition temperature of PBT rich phase, whereas it drops at that of PC rich phase for $30 / 70$ to $0 / 100$ blends. Young's modulus and yielding stress of PBT/PC blends are higher than those estimated by assum. ing the additivity. Therefore, must be strong interactions between PBT and PC chains. The amount of transesterification occurring between PBT and PC chains is too little to be observed by FT-IR. Accordingly, the interaction can be caused by rearrangement of chain packing with mutual diffusion of the chains. This indicates partial miscibility between PBT and PC chains in the melt state. The crystallization of PBT chains in the blends is restrained by PC chains. In the PBT rich phase, crystallization rate becomes slower and the cold crystallization becomes unclear with diffusion of PC chains. On the other hand, PBT chains in the $P C$ rich phase crystallize suddenly when the temperature exceeds the glass transition temperature of the phase. The morphology and the higher glass transition become clear by addition of DNOP. It is considered that DNOP accelerates the degradation of PBT chains.
\end{abstract}

(Received June 12, 1990)

\section{1. 藉言}

高分子材料の用途は近年多様化・複雑化してきてお り，従来の材料ではカバーしきれなくなってきている。 しかし新しい高分子材料を開発・実用化するには長い期 間を要し，多様な高分子材料の需要に対応することは困
難である。これに対し既存の高分子材料間のブレンド *この報文を「ポリブチレンテレフタレート/ポリビス フェノールAカーボネートブレンド物と溶融紡系緎 維の檴造および物性(第 1 報), Structures and Properties of Poly(butylene terephthalate/Poly(bisphenol A carbonate) Melt Blend and Its Melt Spun Fiber (Part 1)」とする。 
は，比較的短期間で各用途に対応した性能を持たせるこ とが可能であり，コストパフォーマンスの改善も期待で きることから，近年期待が集まってきている(1-3]。 ポリブチレンテレフタレート(以下 PBT)

$$
+\left(\mathrm{CH}_{2}\right)_{4}-\mathrm{O}-\underset{\mathrm{O}}{\mathrm{C}}-\mathrm{O}-\mathrm{C}_{\mathrm{O}}^{\mathrm{C}}-\mathrm{O}+_{\mathrm{n}}
$$

は1971年，セラニーズ社により工業生産が開始された樹 脂である。PBTは結晶性ボリマーであり，結晶化速度 は，ポリエチレンテレフタレートよりも速い[4]。また 耐薬品性・成形性に優れ、コネタター用材料などとして 多用されている。その反面ガラス転移温度が室温付近と 低いため耐熱性に劣り，まだ結晶性が高いことから一般 に耐衝撃性も劣る。

一方ポリビスフェノール Aカーボネート(以下 PC)

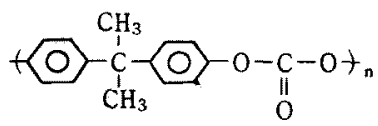

は結晶化しにくい高分子であり，ガラス転移温度が高い $\left(145^{\circ} \mathrm{C}\right.$ 前後 $)$ とから耐熱性に優れ，䡎衝繋性にも優れ る反面，分子鎖密度が低いことから藥品の拡散が速く， 一般的に耐薬品性に劣る。以上の事から $\mathrm{PBT} / \mathrm{PC}$ ブレ ンドは，ポリマープレンド設計の主要三要素[5]（酎熟 性，成形性，強勒性)を渵足し，PBT，PC それぞれの特 性を生かした改質が期待できる。

$\mathrm{PBT} / \mathrm{PC}$ ブレンドの物性は単に分率のみでなく，相分 離によって形成されるモルフォロジーに大きく影響され る[6-18]。溶媒フレンドの場合, PBT 成分と PC 成分の ガラス転移が共に観察され，各ガラス転移温度 $(\mathrm{Tg})$ が 分率によって変化しないことから，非相溶柔とみなせ る。これに対し溶融ブレンドの場合には $\mathrm{Tg}$ の移動が観 測され，雨者の間になんらかの相互作用が存在する。こ の相互作用について，Paul ら〔6]は動的粘弾性測定の 結果より而者間の部分的相溶性老提案し，Devaux ら （9-13）は赤外吸収スペタトル及び核磁気共鳴スペクト 儿測定の結果から，エステル交換による共重合体の生成 を示啳している。Devaux らはさらにリン酸ジオクタデ シル(以下 DNOP)の添加によりエステル交換を阻止でき ることを報告している。

$\mathrm{PBT} / \mathrm{PC}$ 溶融ブレンド物のモルフォロジー形成には溶 瀜時の相互作用と冷却時の相分離㧍よび結晶化等が関倸 し，非常に複雑である。Hobbs ら[14-17] およびDe lemoy ら[18]の透過型電子影微鏡観察により，PC 分率 $60 \%$ 以下ではPC が，そ机以上では PBT が連続相であ ることを明らかにした。さらに PBT が結晶化する際，
結晶ラメラは PBT・PC 界面から成長し、PC 相のガラ 又転移温度以下では成長が抑制されることを報告してい る。

本報文ではPBT，PC，DNOP を混合した溶融ブレン ド䄉維を作成し，FT-IR，DSC，X 楾回折の各湘定およ び電子顕微鏡観察により，各成分の分率が分散状態と相 互作用に与える影響についで明らかにした。また動的粘 弾性測定および引張試験によって機械的物性を測定し た。

\section{2. 実験}

\section{1 試 料}

良好な分散状態を得るためには両高分子の粘度に差が ない方が好ましい。そこでPBTには高粘度タレードで ある帝人社製 PBT(TRB-H)，PCには低粘度グレードで ある三菱瓦斬化学社製 $\mathrm{PC}(\mathrm{H}-3000)$ を使用した。

混合状態を改善するため各高分子チップはあらかしめ

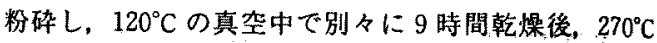
の一軸溶蛀押出装置内で約 8 分溶融混合した。試料は押 出した樹脂を自由落下，もしく任低速で巻取っだしのを 使用した。各分率について DNOPを $0.5 \mathrm{wt} \%$ 混入した試 料も作成した。

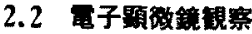

日本電子社製 JSM-25型走查電子影微鏡により加速電 圧10kVで試料断面を観察した。試料はエポギシ樹脂で 包埋，液体窑素中で割断し，両成分の分布を観察し易く するため 4 vol\%塩化メチレンー四塩化炭素混合液に10 時間浸漬し，PCに富む成分を溶解抽出した。

\section{$2.3 \times$ 線回折强度测定}

理学電気社製 $X$ 楾回折装置を用い, Niフィルターで 单色化した $\mathrm{Cu}-\mathrm{K} \alpha$ 線を光源として回折角方向の強度フ ロフィールを湘定した。試料は各分率の試料を $180^{\circ} \mathrm{C} の$ シリコンオイル中で 2 時間熱処理して結晶化させたも の、及びアセトンに24時間浸漬して結晶化させた PC 試 料である。

\subsection{DSC}

セイコー1\& E 社製 DSC-10により昇温速度 $5{ }^{\circ} \mathrm{C} / \mathrm{min}$ で示差走查熱量測定を行った。試料は各々 $10 \mathrm{mg}$ ，測定 温度範囲は $-100^{\circ} \mathrm{C}-280^{\circ} \mathrm{C}$ である。

\section{5 赤外線吸収スペクトル}

パーキンエルマー社製1640型 FT- $\mathrm{IR} に よ り 500 \mathrm{~cm}^{-1}$ $-4000 \mathrm{~cm}^{-1}$ の吸光度スペクトルを測定した。

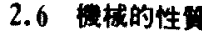

東洋測機社製 TENSILON UTM-IIによらヤング事およ び降伏強度を求めた。試長は $50 \mathrm{~mm}$ ，引張速度は $20 \%$ / min である。また東洋測機杜製直読式粘弾性測定器 


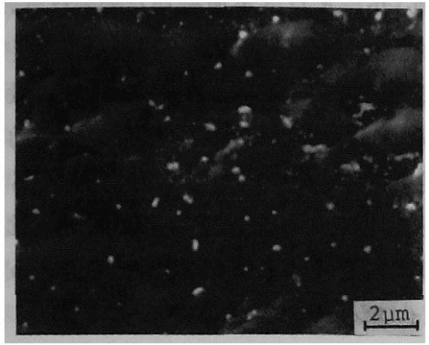

A

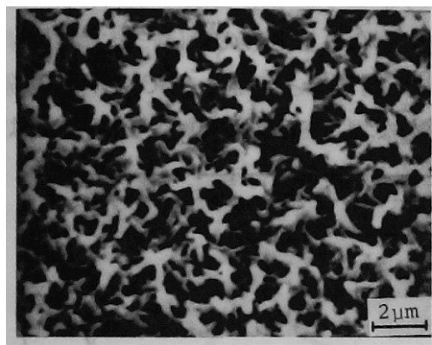

D

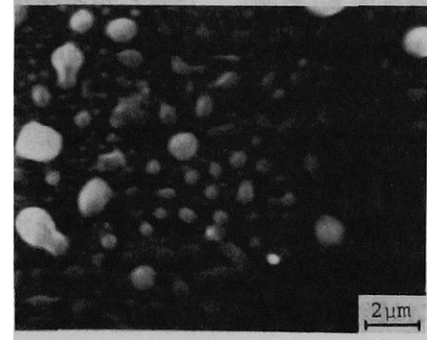

B
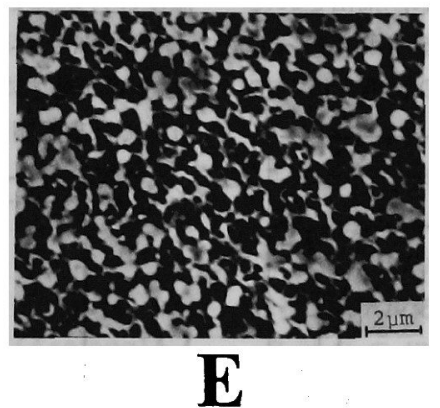

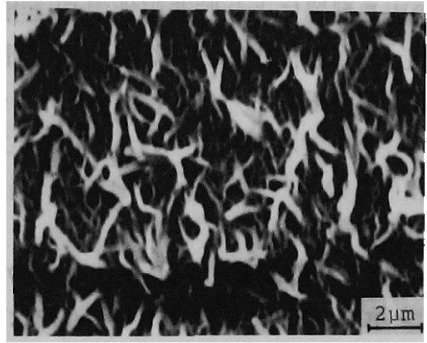

C

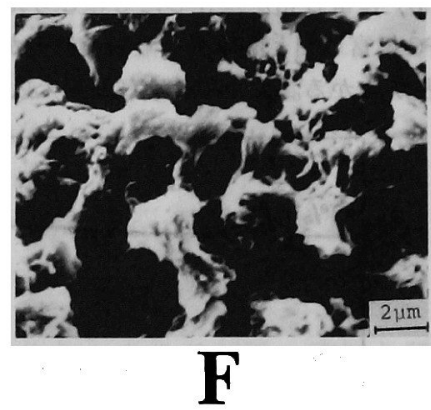

Fig. 1. Scanning electron micrographs of PBT/PC/DNOP blends: (A) 100/0/0.5, (B) $90 / 10 / 0.5$, (C) $70 / 30 / 0.5$, (D) $50 / 50 / 0.5$, (E) $30 / 70 / 0.5$ and (F) $10 / 90 / 0.5$.

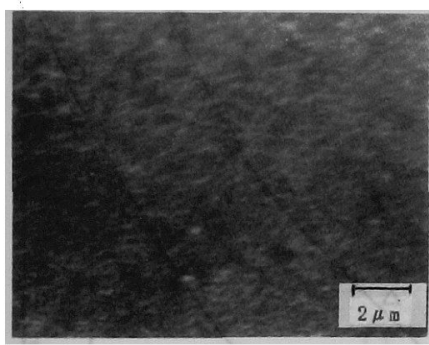

A

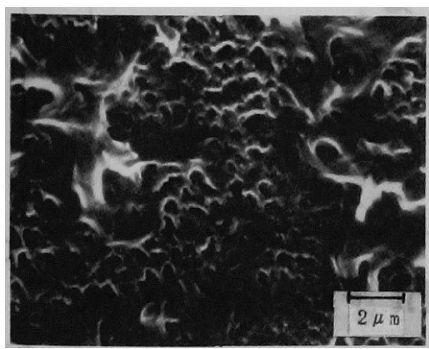

D

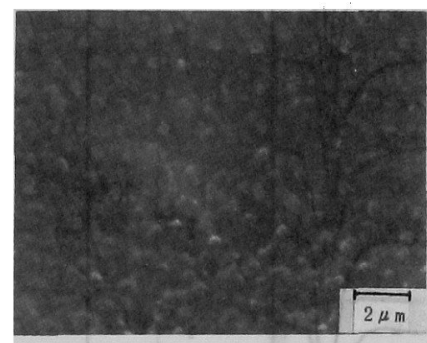

B

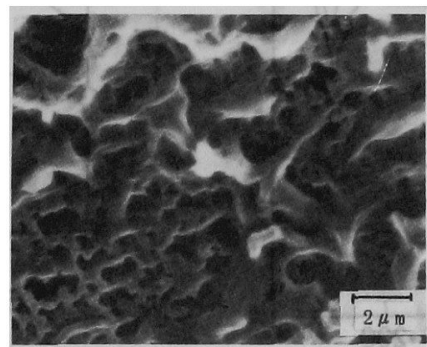

E

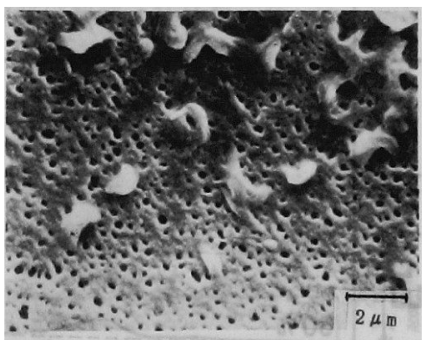

C

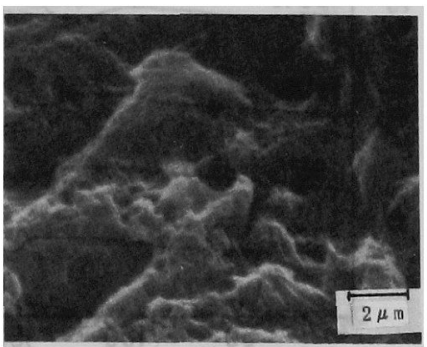

F

Fig. 2. Scanning electron micrographs of PBT/PC blends: (A) $100 / 0$, (B) 90/10, (C) 70/30, (D) 50/50, (E) $30 / 70$ and $(F) 10 / 90$. 
DDVーII 型器により眝蔵弾性率 E' と損失弾性率 E”を測 定した。測定周波数は $110 \mathrm{~Hz}$ ，測定温度範囲は $-70^{\circ} \mathrm{C}-$ $160^{\circ} \mathrm{C}$ である。

\section{3. 結 果}

\section{1 分散形態}

図1に PBT/PC/DNOP ブレンドの走查電子顕微鏡写 真を示す。PC 分率 0-10\%の試料表面には路閏による と考えられる凹凸が見られるが，抽出された痕跡はな く, PC が完全に PBT 内に溶け込んだ 1 相構造である。 PC 分率30-70\%では編目状の構造が見られる。これは PBTに富む相が残存したものと考えられ，抽出された $\mathrm{PC}$ に富む相と明確に分噰した搆造が形成されているこ とがわかる。また PC 分率が $90 \%$ 以上の試料では PBT

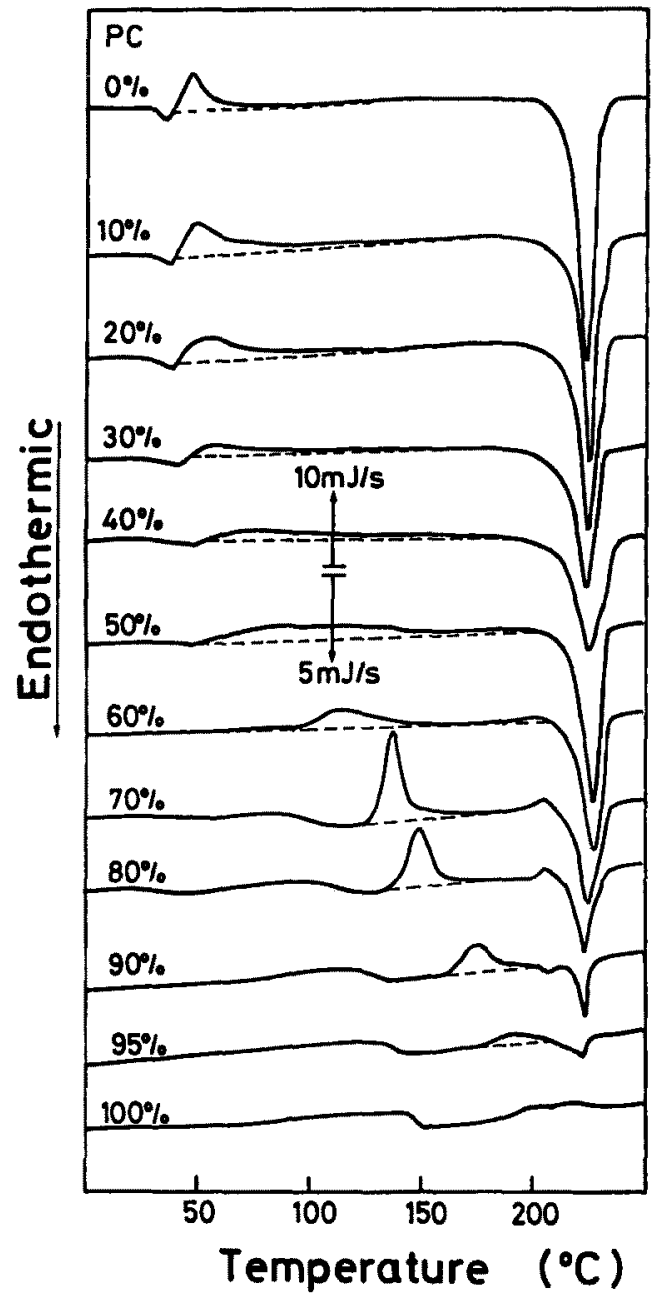

Fig. 3. DSC scans at $5{ }^{\circ} \mathrm{C} / \mathrm{min}$ on $\mathrm{PBT} / \mathrm{PC}$ blends. Weight fractions of $\mathrm{PC}$ are indicated.
に富む相が存在しないか、または不連続なため，PCに 富む相の抽出に伴って全体が溶解する。

図 2 にDNOPを混入していない試料の走查筆子影微 鏡写真を示す。 $\mathrm{PC}$ 分率10\%以下及び $90 \%$ 以上での拳動 は DNOP 非混入のものとあまり䓔がないが，30-70\% では DNOPを混入したものよりも網状情造が太く，量 も多く見える。この檬にごく小昷の DNOPを混入する ことによってモルフォロジーは大きな影製を受ける。

\section{2 ガラス転移}

DSC 測定の結果を図 3 に示す。また低温側のベース ラインと最大傾斜線との交点として定義したガラス転移 温度(O)を図 4 に示す。ガラス転移温度は PC 分率 $60 \%$ まではやや上界傾向がみられるもののほほ一定であり， PC 分事が增すにつれて弱くなってゆく。PC 分率か750\% 以上では高温側に新たなガラス転移が現れ，その温度は

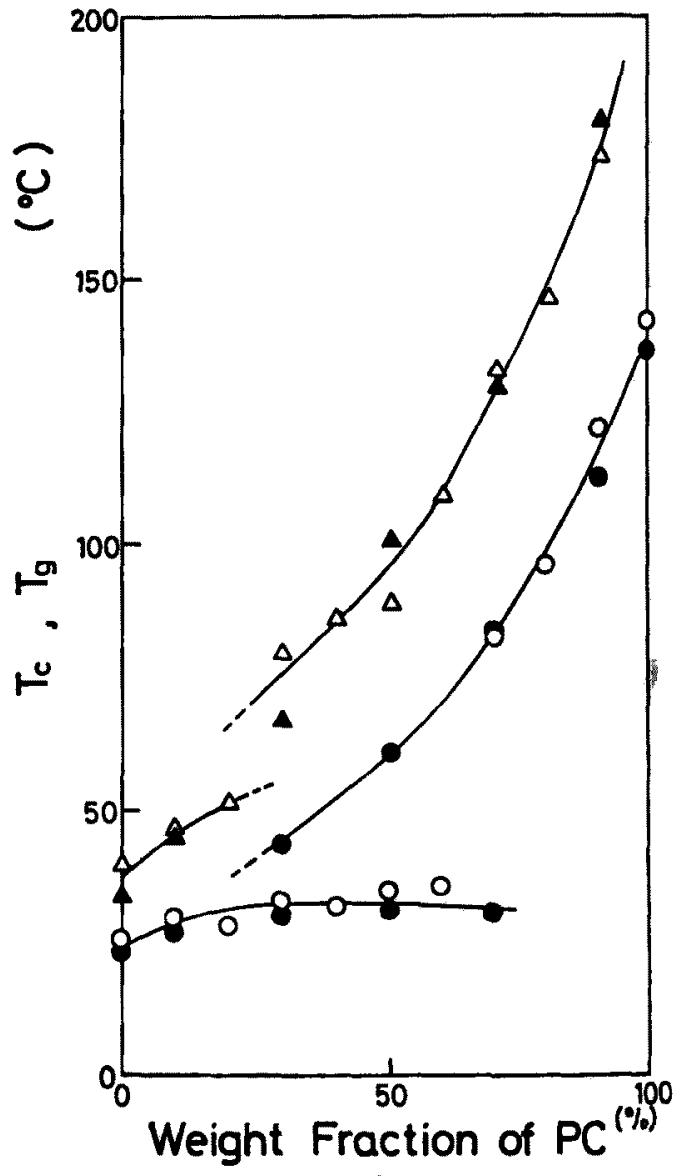

Fig. 4. Plots of glass transition temperature $(\mathrm{O}, \mathbf{0})$ and cold crystallization temperature $(\Delta, \Delta)$ against fraction of $\mathrm{PC}$. Closed marks indicate those samples contain $0.5 \%$ DNOP by weight. 
分率の増加に従って上昇してゅく。DNOPを湿入した試 料のガラス転移温度(○)，低温結晶化温度(A)を図 4 に 示す。これらは DNOP 非混入のものとほとんど差がみ られないが，PC 分率30-70\%の試料では高温側のガラ 又転移が観塞できるようになった。この分率はSEMに よる観察で明暸な 2 相構造が観察される分率と一致す る。従ってここで観察されるガラス転移のうち，低温側 のものはPBTに富む相，高温側はPCに富む相による ものであろう。

\section{3 結晶化}

各分本の試料は溶融混合後，ノズルから自由落下させ て作成したものであり，PBT100\%の試料を除いて非晶 性である。これらを熱処理したものの X 線回折強度曲 線を図 5 に示す。結晶化したPBT 試料では回折角 $17^{\circ}$, $23^{\circ} ， 25^{\circ}$ にそれぞれ $\alpha$ 型結晶の $(010) ，(100) ，(104)$ 各

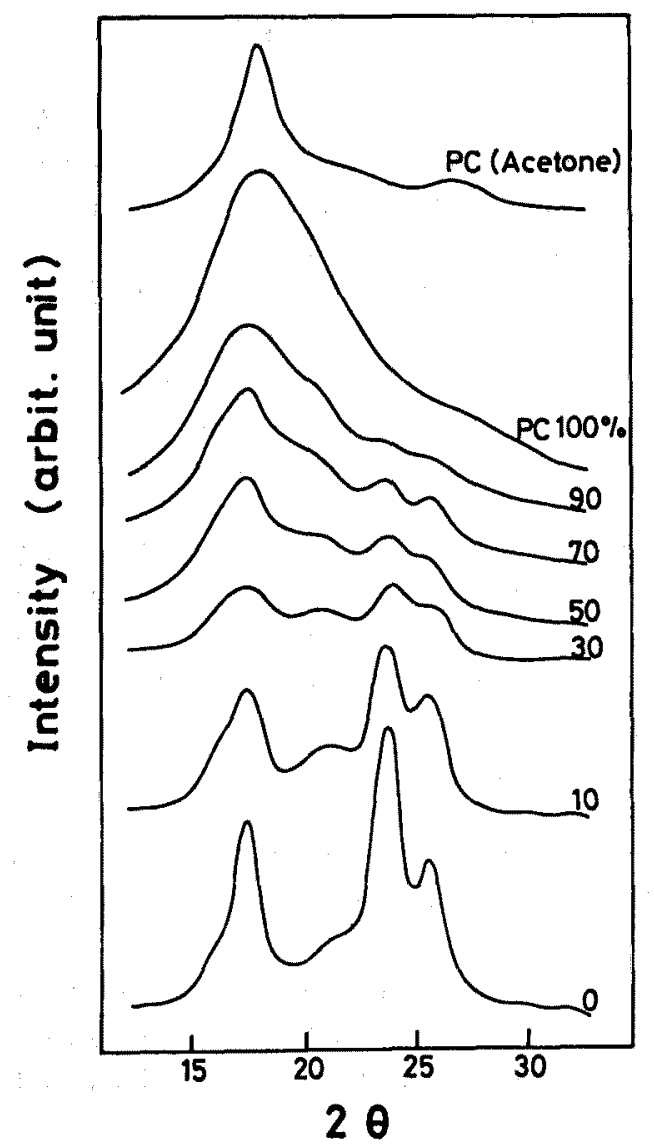

Fig. 5. X-ray diffraction profiles of crystallized $\mathrm{PBT} / \mathrm{PC}$ blends and acetone-treated (crystallized) PC. Weight fraction of PC are indicated. All blends show dif. fraction pattern of PBT crystal only.
面に対応する回折が観察される。またPC 試料は熱処理 しても結晶性の回折は見られないが，アセトン処理した ものでは $19^{\circ}$ 付近のビークが鋭くなり，27付近にもビ ークが現われる。これはPCの分子鎖間秩序性が增した ことを意味し、 Multer ら(19) はこれを PCの結晶とし て扱っている。

各試料を熱処理すると結晶性の回折が現われ、その回 折角はいずれもPBT 結晶のものと同一である。従って DSC 測定で観測された低温結晶化はPBTによるもので ある。

低温結晶化温度はほはPC 分率の増加とともに上昇 し、ピータ温度にはDNOPの影響は見られない(図 4)。低温結晶化ピークはPC 分率50\%以下では分率が 增すほど幅広になるが，それ以上では再び鋭くなる。ま たDNOPを混入した試料では PC 分率50\%でも鋭い低温 結晶化ビークが現われる。

結晶融解温度は DNOP の混入・非混入・PC 分率によ らずほほ一定である。

\section{4 エステル交换}

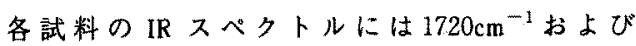
$1780 \mathrm{~cm}^{-1}$ に吸收が観測され，それぞれ $\mathrm{PBT}$ および PC のカルボニル基伸縮振動に対応する。しかし共重合物が 生成した場合にこれらの中間に出現する(10) $1740 \mathrm{~cm}^{-1}$ および $1770 \mathrm{~cm}^{-1}$ の吸収は観測されなかった。従ってエ ステル交換の量はごく少ない。

\section{5 力学的性貲}

図 6 に初期弾性率㧍よび降伏強度のPC 分率依存性を 示す。PBT $100 \%$ 試料のみは結晶化しているため, 非晶 試料の初期弾性率は PC 分率に対し上に凸になると考え

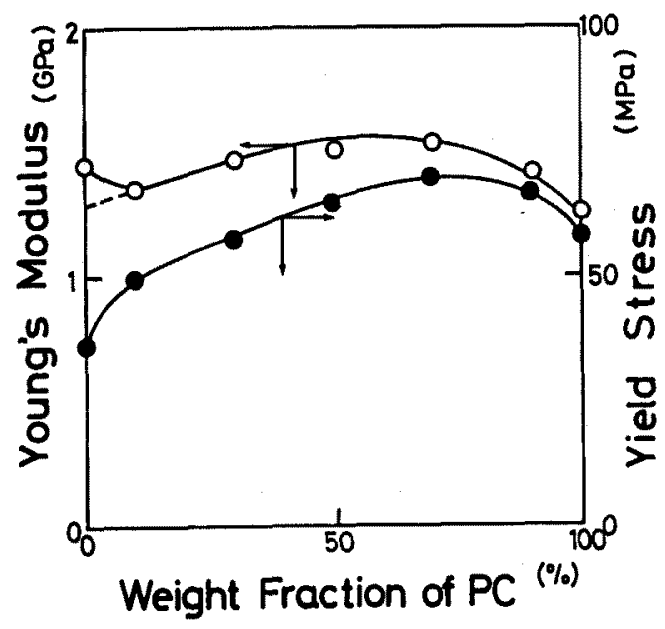

Fig. 6. Plots of Young's Modulus (O) and yielding stress (O) against weight fraction of $\mathrm{PC}$. 


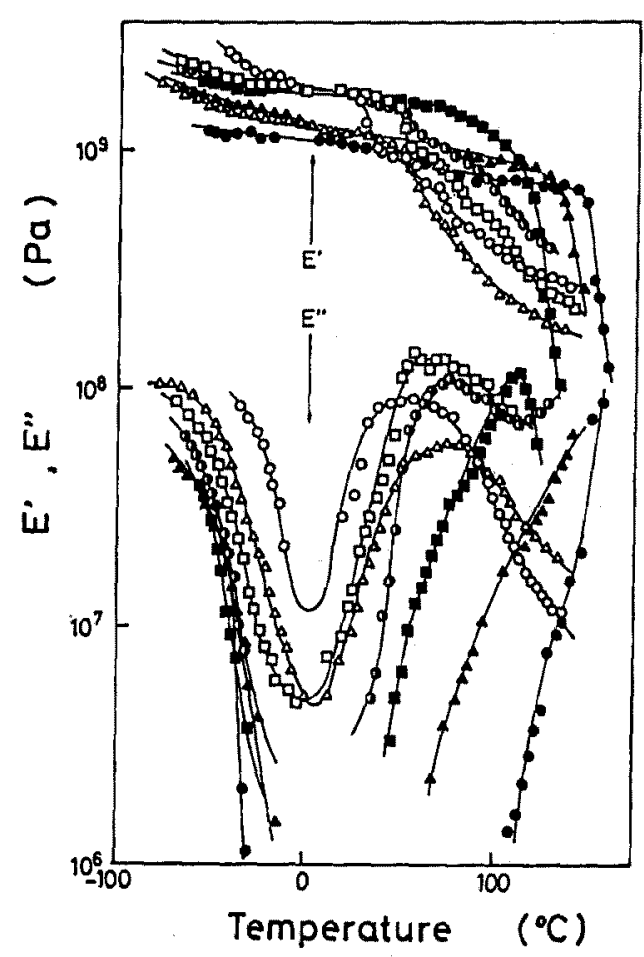

Fig. 7. Strage modulus ( $\left.E^{\prime}\right)$ and loss modulus ( $\left.E^{\prime \prime}\right)$ of PBT/PC blends: (O) $100 / 0,(\triangle) 90 / 10$, ( $\square$ ) $70 / 30$, (C) $50 / 50$, (D) $30 / 70$, (A) $10 / 90$, and (O) $0 / 100$.

られる。降伏強度も同様に上に凸である。非相溶系の場 合, 初期弾性率は PC. 分率に対して一般的に下に凸にな る。従って PBT/PCブレンドは分子鎖間に相互作用が 存在する部分相溶系である。この様に弾性率が分率にた いして上に凸の関係を示すものとしてはPPO/PS 系があ り〔21]，この場合には全組成にわたって相溶性である。

次に動的粘彈性により得られた E'と $E^{\prime}$ の温度依存性 を図 7 に示す。Eの減少，E”の增加が始まる温度は， PBT $100 \%$ では $26^{\circ} \mathrm{C}$ 付近, PC 分率 $10-50 \%$ では $40^{\circ} \mathrm{C}$ 付 近であり，PBTに富む相のガラス転移温度に相当する が，PC 分率70\%以上では PC に富む相のガラス転移温 度に对応するようになる。従ってPC 分率0-50\%では PBT に富む相，70\%以上ではPCに富む相の挙動が機械 的性質を支配する。

\section{4. 考 察}

\section{1 分子鎖間相互作用}

PBT-PCは溶液混合では非相溶性だが，溶融混合によ り相互作用を示す。この原因としては，1）高温で相溶 性になるUCST 型の相図を示すため，2）溶融混合に
伴う化学反応(エステル交換反応など)によってPBT-PC 分子鎖間の親和性が增大するため，などが考えられる。 本研究で扱った試料の場合, FT-IR 測定の結果加考 えてエステル交換に伴う共重合体の生成は少ない。これ は溶融混合時間が約 8分間と每いためであろう。谜って $\mathrm{PBT}$ とPCは溶融状態で少なくとも部分的な相溶性を示 しここれが急冷凍結されたために相互作用が生じる。

\section{2 結晶化}

図3に於てPBT 100\%以外の試料は非晶性だが，ほほ PBT 成分の分率に対応した融解熱を示す。従って PBT の結晶性そのものが減少したわけでは無い。結晶化熱と 融解熱はほほ等しいはずだから、ベースラインは各々圆 の破線の付近と考えられる。

PC 分率 $50 \%$ 以下で低温結晶化しているのは，主に PBT に富む相内のPBTであり，PC分率の增加にした がって低温結晶化ピークの温度幅が広がり, 高温側に移 動するのは，この成分の結晶化速度が遅くなるためであ ろう。

一方 PC 分率60\%以上では PCに富む相のガラス転移 温度よりも高温側に鋭い低温結晶化ピークが現われる。 これは PCに富む相に含まれる PBT 成分の結晶化を表 わす。PC 分率を申, PBT に富む相に含まれる PC成分 の最大分率を $\mathrm{F}_{3}, \mathrm{PC} に$ 富む相に含まれる $\mathrm{PC}$ 成分の最 小分率を $\mathrm{F}_{2}$ とすると，PCに富む相に含まれ交 $\mathrm{PBT}$ 成 分の量住，

$$
\begin{aligned}
0 & : \phi<F_{1} \\
\left(1-F_{2}\right)\left(\phi-F_{1}\right) /\left(F_{2}-F_{1}\right) & : F_{1}<\phi<F_{2} \\
1-\phi & : F_{2}<\phi
\end{aligned}
$$

で与えられる。これは $\phi=\mathrm{F}_{2}$, 即ち 2 相構造が $\mathrm{PC}$ に富 む相の1相構造に变わる分率で最大になる。SEM 観察 およびガラス転移温度の挙動よク， $F_{2}$ は70-90\%であ り, 高温倒の低温結晶化ピークが PC 分率70-80\%で最 大になることと符合している。

\subsection{DNOPの効果}

DNOP をご少量加えることにより，モルフォロジー や流動挙動が大きく变化すること[20]は注目に值す る。DNOPは融液中で解離し，PBT・PCの分子鎖末端 に結合することにより両者のエステル交換を阻害する。 本研究で用いた試料の場合，もともと工ステル交换の量 が少ないため，むしろこれに伴う分子量低下の影響の方 が大きいと考えられる。DNOPは長い炭化水素基を含む ためPCよりも PBT との親和性が高く、PBT 相に集中 する。この結果, 主にPBT とDNOP との間でエステル 交換反応が生じ，PBTの分子量が顕著に隇少す る[20]。DNOPの混入によって而相がはっきり分離して 観察されるようになり，ガラス転移及び低温結晶化ピー 
クが鋭くなるが、これは分子量低下に伴って PBT 分子 鎖の運動性が增し，相分離・結晶化が速くなるためであ ろう。

\section{5. 結 論}

$\mathrm{PBT}$ と PCを各種の分率で溶融ブレンドし，得られた 試料について DSC, X 線回折, FT-IR の各測定㧍よび 電子顕微镜による観察を行った。また緎維状試料を作成 し，機械的性質及び動的粘弾性の測定を行った。 PBT/PCブレンドのモルフォロジーはPC 分率10\%以 下では単一相，30\%-70\%では 2 相，70\%を超えると再 び単一相が観察された。また初期弾珄率，降伏強度は PC 分率に対して上に凸の関係を示し，PBT-PC 分子顉 間の相互作用を考える必要がある。相互作用の原因とし ては分子鎖の相互搪散による分子鎖パッキングの改良が 考えられ，溶融状龍で PBT-PC 間に部分的な相溶状態 が生じていることを示唆する。

ブレンド中の PBT 成分は PC 成分の束縛を受けるた め、結晶化し難くなる。PBTに富む相内では PC成分の 搪散に伴って結晶化速度が低下主る結果, 低温結晶化ピ 一クが不明瞭になる。一方 PCに富む相内ではこの相の ガラス転移温度以上で結晶化が可能になり，鋭い低温結 晶化ピークが観察される。

DNOPの混入により電子顕徽鏡観察像およびガラス転 移，低温結昆化が明瞭になるが，これは主にPBT 成分 の分子量が低下するためであろう。

付 記：本研究に際し，実験を抢手伝いいただいた土屋 掑子技官に御礼申し上げます。本研究の一部は䄉維学会 昭和62年度年次大会研究発表会(6月15日・東京) および 峨維学会昭和 63 年度年次大会研究発表会 $(6$ 月 13 日 - 東 京)にて発表した。

\section{文献}

1. 高分子学会編,「ポリマーアロイ基礎と応用」, 東京 化学同人 (1981)

2. 西 敏男, 秋山三郎, 井上 隆,「ポリマーブレン゙ F」, CMC (1981)
3. 高分子学会編,「ポリマーアロイ」, 共立出版 (1988)

4. C. F. Pratt and S. Y. Hobbs, Polymer, 15, 407 (1974)

5. 綾 敏彦, 高分子, 37, 802 (1988)

6. D. R. Paul, D. C. Wahrmund, and J. W. Barlow, $J$. Appl. Polym. Sci., 22, 2155 (1978)

7. W. Birley and X. Y. Chen, Brit. Polym. J., 16. 77 (1984)

8. B. D. Hanrahan, S. R. Angeli, and J. Runt, Polym. Bull., 14, 399 (1985)

9. J. Devaux, P. Godard, and J. P. Mercier, J. Polym. Sci, Polym. Phys. Ed., 20, 1875 (1982)

10. J. Devaux, P. Godard, and J. P. Mercier, J. Polym. Sci, Polym. Phys. Ed, 20. 1881 (1982)

11. J. Devaux, P. Godard, and J. P. Mercier, J. Polym. Sci., Polym. Phys. Ed., 20, 1895 (1982)

12. J. Devaux, P. Godard, and J. P. Mercier, J. Polym. Sci., Polym. Phys. Ed., 20, 1901 (1982)

13. J. Devaux, P. Godard, and J. P. Mercier, Polym. Eng. Sci., 22, 229 (1982)

14. S. Y. Hobbs, V. L. Groshans, M. E. J. Dekkers, and A R. Shultz, Polym. Bull., 17, 335 (1987)

15. S. Y. Hobbs, M. E. J. Dekkers, and V. H. Watkins, Polym. Bull., 17, 341 (1987)

16. S. Y. Hobbs, M. E. J. Dekkers, and V. H. Watkins, $J$. Mater. Sci., 23, 1219 (1988)

17. S. Y. Hobbs, M. E. J. Dekkers, and V. H. Watkins, $J$. Maler. Sci., 28, 1225 (1988)

18. D. Delemoy, C. Bailly, J. Devaux, and R. Legras, Polym. Eng. Sci, 28, 104 (1988)

19. A. Multer, G. Difilippo. M. Gonzalez, and M. Gasiba, J. Appl. Polim. Sci., 34, 1959 (1987)

20。近田淳雄，大越 豊，三枝伸司，青木茂人，鳥海浩 一郎, 耭学誌, 47, 72 (1991)

21. L. W. Kleiner, F. E. Karasz, and W. J. Macknight, Polym. Eng. Sci., 19, 519 (1979) 